\title{
A Comparative Study of the Socio-ecological Concomitants of Cassava (Manihot esculenta Crantz) Diversity, Local Knowledge and Management in Eastern Indonesia
}

\author{
Roy Ellen and Hermien L. Soselisa
}

\section{Research}

\begin{abstract}
We compare cassava (Manihot esculenta Crantz) diversity, local knowledge and management practices in two eastern Indonesian populations that differ both ecologically and socioculturally (Nuaulu on the island of Seram, and Debut in the Kei archipelago) and make some reference to a third population (Buano, west of Seram). The report is set within the wider problem of understanding the differences and similarities between $M$. esculenta in its homeland (South America) and in its diaspora, and specifically in island Southeast Asia. We show how under different conditions the importance of diversity and of toxicity varies, and how in particular this is related to environmental degradation and biocultural aspects of food ecology.
\end{abstract}

\section{Introduction}

Population growth and the minimization of agricultural risk over the long-term in island Southeast Asia has been accommodated through, on the one hand, intensification of rice cultivation and, on the other, by extensification of alternative crops. As part of the second trend, there has been a historical process of substitution of pre-Columbian crops with those introduced from the Americas, most saliently maize, sweet potato, and cassava (Manihot esculenta Crantz, Euphorbiaceae). ${ }^{1}$ Cassava was certainly

1. The predominant English names for M. esculenta are 'manioc', in the context of the Americas, and 'cassava', in the context of Africa and Asia. Given that this paper seeks to compare the crop between these two land-masses the different conventions need to be mentioned. For consistency and pragmatic reasons we use 'cassava', the most commonly used term overall, aware that others have argued in favor of the universal application of 'manioc' (Gade 2002). present in parts of the archipelago by the eighteenth century, but did not attain significance until the late nineteenth century. It is now widely found both as a staple of first choice and as a main buffer crop (Hill 2004).

Most work on the ethnobotany of cassava has been undertaken in tropical lowland South America, where the main focus has been on its origins as a domesticated crop and on issues of diversity management (e.g., Boster 1983, 1984a,b, 1985, 1986, Elias et al. 2000, 2001a, Rival et al. 2000, Rival \& McKey 2008). Indeed, Amazonian cassava is sometimes said to exhibit 'hyperdiversity' (Heckler \& Zent 2008), for example, the 204 folk-varieties $^{2}$ reported by Salick et al. (1997) for the Amuesha. This has been explained in terms of adaptation to a range of microecological (Boster 1983, Hames 1983) and temporal (Clawson 1985) niches; and where the levels of functional redundancy are too high to be plausibly explained in

\section{Correspondence}

Roy Ellen, University of Kent, Canterbury, UNITED KINGDOM. rfe@kent.ac.uk

Hermien L. Soselisa, Universitas Pattimura, Ambon, INDONESIA.

hlsoselisa@hotmail.com

Ethnobotany Research \& Applications 10:015-035 (2012)

Published: March 22, 2012

www.ethnobotanyjournal.org/vol10/i1547-3465-10-015.pdf 
terms of adaptation, ethnobotanists have suggested that it might be a product of an aesthetic for diversity (Boster 1984b:356, Salick et al. 1997:6) and a social imperative to exchange (Heckler \& Zent 2008).

By comparison, most of what we know of cassava in the diaspora focusses on agronomic issues and the problem of toxicity. Little is known, for example, of diversity management in diasporic Southeast Asia compared with South America. Given the contrasting biogeographic, ecological and sociocultural contexts of cassava in South America and the rest of the world, we might reasonably ask whether the socio-ecological dynamics of this cultigen in the diaspora are the same as those found in its area of endemism. In this paper we test the hypothesis that diasporic conditions of cassava management are different, and do so mainly through a comparative study of two populations of cassava producers and consumers in eastern Indonesia, specifically in the province of the Moluccas (Maluku). This is an ecologically transitional area, diverse in terms of its habitats, marginal in terms of economic development, and complex in terms of both the movements of humans (including spontaneous and government-assisted migrations), the flow of plant germplasm, and the cultural knowledge that accompanies this latter. For both populations we compare the biological diversity of cassava present, local knowledge of cassava and its social distribution, its management, dietary role and sociocultural profile.

In the context of some of the issues of food security that have recently been discussed in the literature (e.g., Ellen 2007), we examine the way in which cassava folk-varieties have become established as part of differing local strategies of risk management and resilience. We therefore also seek to test: hypothesis 1 , that the importance attached to cassava is related to its relation to other crops and local ecology, as well as to socioeconomic risk factors; hypothesis 2, that cassava is likely to become increasingly important with specialist commercial cropping, deforestation, climate change and attendant social system insecurity and instability; and hypothesis 3 , that the bitter landraces are better adapted to poorer soils and drier micro-climates. We argue that the divergence between our two main study sites relates to the different ecologies of central Seram and the Kei islands, but also to the substitution of cassava for Metroxylon sagu Rottb., which until recently was not only widely-grown but also widely traded in the south-eastern Moluccas.

\section{Environmental and Ethnographic Context}

The two main populations compared are the Nuaulu of the south central part of the island of Seram (in particular the village of Rouhua), and Debut on the island of Kei Kecil. We also make reference to a third research site: Buano, a small island off the western end of Seram. Although all locations can be broadly characterized as permanently moist (udic) with much the same rainfall distribution, as we shall see there are some significant agroclimatic differences between Seram and Kei. The geographic relationship between the populations is shown in Figure 1, each being linguistically related within the Ambon Timor group of the Austronesian family. The Rouhua fieldwork was undertaken by Ellen in August 2009, who had previously conducted research extensively on Nuaulu subsistence. The Debut research was undertaken jointly by Soselisa and Ellen in August 2009. Fieldwork in Buano was conducted by Soselisa between 1997 and 2000, and (for this project) again in 2009.

The Nuaulu are a discrete cultural group speaking a distinct language who in 2009 occupied six villages in the Amahai subdistrict of south Seram, and who numbered 1686 individuals in 2001. In addition, speakers of Nuaulu presently occupy the village of Wai Pia where they have re-located following displacement during communal disturbances between 1999 and 2002. The present study was conducted in the village of Rouhua, located at $3^{\circ} 21^{\prime}$ S, $129^{\circ} 08^{\prime} \mathrm{E}$ on the south coast of Seram immediately east of the large settlement of Sepa, and which in 2009 had a total population of 508, 402 of which were animist and native speakers of Nuaulu, and who are the subjects of the present study. Thus, data were not gathered from recent Butonese migrants or people from Sepa who also currently reside in Rouhua. Vegetation cover in the Nuaulu area is predominantly evergreen lowland forest with some semi-evergreen and moist deciduous forest (Ellen 2010). The dry season is October to March and the wettest season May-August, with a total mean annual rainfall of $2832 \mathrm{~mm}$ (Ellen 1978:213), though official records for 2010 indicate $2221 \mathrm{~mm}$ annual rainfall for south Seram, and an average annual temperature of $26.3^{\circ}$ Celsius (Maluku Dalam Angka 2010:27).

Historically an upland and forest swiddening population, for whom the main source of dietary starch is sago $(M$. sagu), we think it likely that cassava was relatively unimportant for Nuaulu for most of the twentieth century. However, by 1970 it had become a plant of major importance, being grown in most swiddens, and representing 15 per-

2. We use the term folk-variety to refer to terms and categories applied to sub-specific variants by local subjects, and landrace when talking generally about relatively stable sub-specific phenotypically-distinguishable variants validated by researchers. Because cassava shows continuous variation throughout its range in every characteristic studied, taxanomic classification beyond the local level is extremely difficult. The terms 'cultivar' and 'variety' are avoided. Some researchers follow Berlin, Breedlove and Raven (1973) in using varietal to indicate the lowest level in a system of ethnobiological ranks, and as a term for local categories recognized by subdividing folk-specifics, but evidently this also is the cause of some confusion. See e.g., Gibson (2009) on the problems in using such terms comparatively. 

esculenta) Diversity, Local Knowledge and Management in Eastern Indonesia

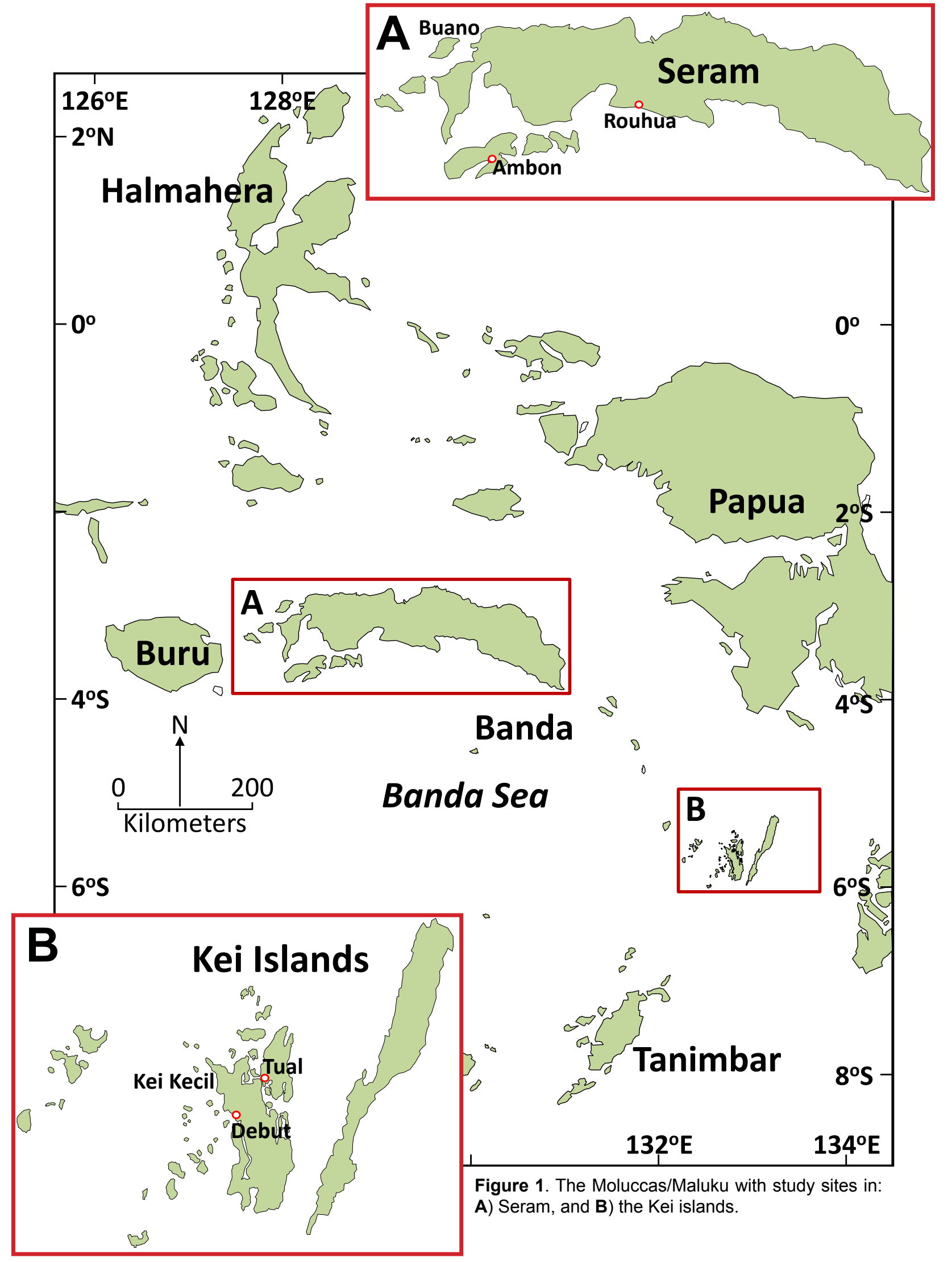


cent of calorific intake compared with 6 percent for all other root crops combined, and 60 percent for sago (Ellen 1973:471). Initially, cassava was planted after other root crops and in second year swiddens, priority being given to species of Dioscorea and taro (Colocasia esculenta (L.) Schott), sweet potato (Ipomoea batatas (L.) Lam.) and to a lesser extent elephant's ear (Xanthosoma sagittifolium (L.) Schott). But although in terms of consumption, cassava had become the most important root crop in terms of output by 1970 , in ritual terms it had no significance, all attention being given to yams (Dioscoerea spp.) and taro, that is to those pre-Columbian crops that had been previously dominant in swiddens.

By comparison, the Kei islands have long been associated in the popular perceptions of other Moluccans as dependent on cassava (or more properly, the fermented flour of the bitter landraces: enbal). Our study location is Debut on Kei Kecil, situated at $5^{\circ} 44^{\prime} \mathrm{S}$ and $132^{\circ} 41^{\prime} \mathrm{E}$ on the west coast of Kei Kecil at the mouth of the Hoat Sorbay (a deep coastal inlet). Debut had a population in 2009 of 2,628 individuals. The dry season is April-October, and the wettest season is December-February. Current rainfall figures for Kei Kecil suggest a range of between 3,000 and $2,000 \mathrm{~mm}$, averaging around $2615 \mathrm{~mm}$. The average annual temperature for Kei is $27.5^{\circ}$ Celsius (Maluku Tenggara Dalam Angka 2010:4-5). While soils in the Nuaulu area are humitropepts (inceptisols), those of Kei Kecil are eutropepts, known to risk nutrient deficiency under certain circumstances unless rich humus top soil is preserved (Monk et al. 1997:118). Vegetation cover is predominantly moist deciduous forest, with some dry deciduous forest and semi-evergreen rainforest, grassland and shrubby savanna (Monk et al. 1997:198, 207). The most common trees in regrowth areas are species of Macaranga. Following Harris (1980), the environment of much of Kei Kecil can be characterized as a mixture of savanna woodland, tree savanna and shrub savanna.

At the present time, Debut is largely dependent on mixed gardening (a combination of swiddens and fixed dryfields near the village) with cassava as the dominant starch staple, some cash-cropping, agroforestry, fishing and 'agaragar' [Hydropuntia edulis (S.G. Gmelin) Gurgel \& Fredericq (syn. Gracilaria lichenoides Greville)] farming in frames located in near shore waters. There has been a government-sponsored agricultural development project in Debut for 3-4 years involving mainly the companion planting of cassava and ground nuts (Arachis hypogaea L.).

But this pattern has not always prevailed. In most of the Kei islands cassava has largely replaced archaic native crops such as the foxtail-millet, Setaria italica (L.) P. Beauv. (Barraud 1985, Monk et al. 1997:704), and Coix lacryma-jobi L., more demanding hydrophilic root crops
(Dioscorea spp., C. esculenta), and - in particular - sago (M. sagu). We hypothesize here that this is related to accompanying environmental change. Over a period of 100 years cassava has become what we might describe as a 'cultural keystone species', playing an important role in social identity as well as food culture (Ellen 2006:259). From a review of the historical data (Ellen \& Soselisa n.d.), it would appear that from the late nineteenth century and early twentieth century onwards Kei Kecil in particular was degraded through heavy timber extraction from the kind of lowland tropical rainforest reported for Seram, compounded by overintensive cultivation (Donner 1986). In his literature review, Nutz $(1959: 14,19)$ characterises the Kei islands at this time as emerging as an intermediate zone between Seram and Buru (with predominant dependence on sago) on the one hand, and Timor and Tanimbar (with predominant dependence on rice) on the other, and where various staples competed, but where cassava eventually prevailed.

This period of environmental transition has simultaneously seen radical sociocultural change. While the Nuaulu remain largely an animist population living at low density on the margins of mature forest with a forest extraction and swiddening mode of subsistence, Debut has moved from being a traditional animist society to a largely Catholic community in about 100 years, with a small Muslim minority. It is also more densely inhabited and integrated into both the state and the market than the Nuaulu area.

Our third, subsidiary, research site, Buano, in some respects lies between the Nuaulu and Kei Kecil in ecological and subsistence terms, and is situated at $3^{\circ} 00^{\prime} \mathrm{S}$ and $127^{\circ} 56^{\prime} \mathrm{E}$. Lowland rainforest is much depleted, and part of the island is covered in savanna grassland characteristically populated by kayu putih trees (Melaleuca cajuputi (J.F. Gmel.) Powell) from which the oil is extracted and marketed. Residents continue to rely on sago, but cassava is of growing importance. Buano is linguistically and culturally closer to the Nuaulu than Debut, but has been largely populated by Christians and Muslims since the seventeenth century. Unlike the traditional Nuaulu area, its coastal location makes it well connected in terms of trading networks.

\section{Nuaulu Cassava Terms and Categories and Knowledge Distribution}

During the 1970s and 1980s Ellen collected data on $M$. esculenta folk-varieties grown by Nuaulu. These data were consolidated in the Nuaulu Ethnobotanical Database (NED) produced after 1996 (see e.g., Ellen 2010:121-2). The Nuaulu term for Manihot is kasipii ${ }^{3}$ from Ambonese Malay (hereafter AM) kasbi. The category includes kasipii sombar (literally 'shade' (AM) kasipii; also AM kasbi karet), Manihot glaziovii Müll. Arg., which is planted main-

3. All Nuaulu terms are standardized using the orthography provided by Bolton and Matoke 2005. In earlier publications by Ellen kasipii appears as kasipi. 


\section{Ellen \& Soselisa - Socio-ecological Concomitants of Cassava (Manihot esculenta) Diversity, Local Knowledge and Management in Eastern Indonesia}

ly as an ornamental and shade plant in village areas, and from which the leaves but not the roots can be harvested. The remaining types of kasipii elicited during all fieldwork phases are all subtypes of $M$. esculenta and listed in Table 1. In this table it should be noted that some folk-varieties have well-known synonyms, where one term is often AM (e.g., Nuaulu honue = AM paru; Nuaulu masikunne = AM mantega). Especially with recently introduced types, AM terms are frequently used even when other Nuaulu terms are available, and in an ad hoc way. For example, kasipii tiga bulan is clearly established as kasipii kanapua. However, although cassava diversity is highly dynamic and the terminology used to describe it not always stable,

Table 1. Nuaulu terms for folk-varieties of Manihot esculenta Crantz, Rouhua 2009. KEY: $w=w h i t e, b=b l a c k, r=r e d, y$ = yellow, r/w = reddish white, w/y = whitish yellow; AM, Ambonese Malay; IND. Indonesian; k.o., kind of; syn, synonym. Note that names in Ambonese Malay are often the same as in standard Indonesian. Therefore, here AM should be understood to refer to names that have come from speakers of AM and speakers of Indonesian as used in the Moluccas.

\begin{tabular}{|c|c|c|c|c|c|}
\hline Nuaulu Term & Meaning & Synonyms & Meaning & AM Term & Notes \\
\hline kasipii paru & $\begin{array}{l}\text { from AM paru, } \\
\text { 'grate' }\end{array}$ & kasipii honue & new & kasbi paru & $\begin{array}{l}\text { eaten only as detoxified flour; } \\
\text { intr introduced by Butonese; } \\
\text { possible semantic conflation } \\
\text { between AM baru } \\
\text { (new)/paru (grate) }\end{array}$ \\
\hline $\begin{array}{l}\text { kasipii masi- } \\
\text { kunne }\end{array}$ & yellow & $\begin{array}{l}\text { kasipii man- } \\
\text { tega }\end{array}$ & margarine & kasbi kuning & $\begin{array}{l}\text { name refers to colour of root } \\
\text { (IND) parenchyma; eaten only } \\
\text { as detoxified flour }\end{array}$ \\
\hline kasipii putie & white & - & - & kasbi putih & $\begin{array}{l}\text { name refers to color of root } \\
\text { parenchyma }\end{array}$ \\
\hline $\begin{array}{l}\text { kasipii un- } \\
\text { uhutu }\end{array}$ & see Notes & - & - & - & $\begin{array}{l}\text { refers to Clerodendron (incl. } \\
\text { blumeanum Schau.); used } \\
\text { medicinally; wood sacred and } \\
\text { prohibited for clan Soumori; } \\
\text { k.o. kasipii putie }\end{array}$ \\
\hline $\begin{array}{l}\text { kasipii wa- } \\
\text { saena }\end{array}$ & $\begin{array}{l}\text { wasa, house } \\
\text { rafter }\end{array}$ & - & - & - & - \\
\hline $\begin{array}{l}\text { kasipii } \\
\text { kanapua }\end{array}$ & see Notes & $\begin{array}{l}\text { kasbi tiga bu- } \\
\text { lan }\end{array}$ & $\begin{array}{l}\text { three month } \\
\text { (IND) }\end{array}$ & $\begin{array}{l}\text { same as } \mathrm{Nu} \text { - } \\
\text { aulu synonym }\end{array}$ & $\begin{array}{l}\text { term refers to Gossypium bar- } \\
\text { badense L. [syn. Gossypium } \\
\text { acuminatum Roxb. ex G.Don } \\
\text { (k.o. cotton plant); AM term re- } \\
\text { fers to quick maturation period }\end{array}$ \\
\hline kasipii buna & see Notes & - & - & - & $\begin{array}{l}\text { refers to variegated leaves, } \\
\text { as in puni or pun (the ar- } \\
\text { oid Homalomena pendula } \\
\text { (Blume) Bakh.f. used to pro- } \\
\text { tect people from the spirits } \\
\text { of children who have died in } \\
\text { childbirth) }\end{array}$ \\
\hline $\begin{array}{l}\text { kasipii sin- } \\
\text { sinte }\end{array}$ & see Notes & $\begin{array}{l}\text { kasipii } \\
\text { Makuana }\end{array}$ & - & - & $\begin{array}{l}\text { sinsinte refers to variegated } \\
\text { Ivs of Codiaeum variegatum; } \\
\text { (L.) Rumph. ex A. Juss. this } \\
\text { character permits their use as } \\
\text { arm decorations in ritual; syn } \\
\text { refers to village of Makuana in } \\
\text { north Seram }\end{array}$ \\
\hline $\begin{array}{l}\text { kasipii msi- } \\
\text { nae }\end{array}$ & red & kasipii postel & - & - & $\begin{array}{l}\text { introduced through Ruatan } \\
\text { transmigration area by Ban- } \\
\text { danese or from Pelauw (Ha- } \\
\text { ruku) }\end{array}$ \\
\hline
\end{tabular}




\begin{tabular}{|c|c|c|c|c|c|}
\hline Nuaulu Term & Meaning & Synonyms & Meaning & AM Term & Notes \\
\hline $\begin{array}{l}\text { kasipii wa- } \\
\text { nate }\end{array}$ & k.o. bamboo & - & - & - & $\begin{array}{l}\text { refers to resemblance of leaf } \\
\text { to k.o. bamboo, probably Gi- } \\
\text { gantochloa atter (Hassk.) } \\
\text { Kurz }\end{array}$ \\
\hline $\begin{array}{l}\text { kasipii ka- } \\
\text { sitena }\end{array}$ & sweet potato & - & - & kasbi patatas & $\begin{array}{l}\text { so-called because of resem- } \\
\text { blance of roots and rootsys- } \\
\text { tem to Ipomoea batatas (L.) } \\
\text { Lam.; k.o. kasipii putie; from } \\
\text { Wai Pia }\end{array}$ \\
\hline $\begin{array}{l}\text { kasipii hata } \\
\text { metene }\end{array}$ & black stem & Hatumeten & [toponym] & - & $\begin{array}{l}\text { possible lexical conflation of } \\
\text { two terms }\end{array}$ \\
\hline $\begin{array}{l}\text { (kasipii) } \\
\text { posteli }\end{array}$ & $\begin{array}{l}\text { from Dutch, } \\
\text { but see Notes }\end{array}$ & - & - & - & $\begin{array}{l}\text { said to be introduced by Bu- } \\
\text { tonese; term is certainly of } \\
\text { Dutch origin, maybe an elision } \\
\text { of 'bastel' (an early twentieth } \\
\text { century variety developed at } \\
\text { Buitenzorg), from bestelling, } \\
\text { or from 'post' or posteren, } \\
\text { meaning guard post }\end{array}$ \\
\hline posteli tone & $\begin{array}{l}\text { k.o. garden } \\
\text { fence }\end{array}$ & - & - & - & - \\
\hline posteli upone & plant tip & - & - & - & - \\
\hline $\begin{array}{l}\text { kasipii Super } \\
\text { Mie }\end{array}$ & see Notes & - & - & - & $\begin{array}{l}\text { so named because, like the } \\
\text { instant noodles with the same } \\
\text { brand name, roots take just a } \\
\text { few minutes to boil; from Bau- } \\
\text { bau (Buton) }\end{array}$ \\
\hline $\begin{array}{l}\text { kasipii mata } \\
\text { rase }\end{array}$ & - & - & - & - & $\begin{array}{l}\text { a folk-variety no longer culti- } \\
\text { vated in Rouhua, but } \\
\text { found along stream edges }\end{array}$ \\
\hline
\end{tabular}

we suggest that it would be accurate to report the existence of around 17 terminologically distinct types.

Figure 2 provides an outline Nuaulu folk classification for cassava based on terminological distinctions. However, the range of types, especially given that most reflect clonal variation, means that these cannot be adequately represented as a taxonomy, and most likely are best represented as a multidimensional paradigm of cross-cutting features based on a range of characteristics (cf. Iskandar \& Ellen 1999). Nuaulu terminology for describing cassava variation involves distinguishing key diagnostic parts of the plant, which are not necessarily the terms used to describe the botanically comparable parts of other plants, and do not precisely map onto scientific plant anatomical nomenclature. However, for cassava: huae is fruit, kanie seed, stem cutting or other reproductive material (AM bibit or stek), naunai flower, totue leaf, kaie petiole, ai (u) kune main stem (as in woody plants), namte root and isie the swollen storage organ (literally meaning 'inside'). The characteristics attributed to each cassava plant recognized as a distinct folk category are set out in Table 2 . To summarize, the main diagnostic perceptual character- istics are: leaf size and shape; color and texture of petiole and stem; appearance of root parenchyma (AM isi), periderm and cortex. In addition, toxicity, taste of both raw root and leaf may be relevant, as may be the softness or hardness of the root, productivity, maturation time, storeability and cooking time.

Depending on what characteristic is stressed, so the shared core classification will vary to reflect this. This can be seen in Figure 2 in relation to kasipii putie. For some people this is an intermediate level category that incorporates all folk-varieties that have white root parenchyma, and sometimes also a white stem and petiole. Thus, Retaone told the first author that there are four kinds of kasipii putie: wanate, kanapua, postel (putie), and wasaena. Others treat the various sub-types as distinct folk-varieties and do not place them in such an over-arching category. For others there is a cross-cutting classification, such that use of the term putie always refers to root parenchyma, and the term wasaena to leaf shape and other external characteristics. Two names, with histories that suggest a recent introduction, refer to 'bitter' folk-varieties and are only used when the toxins have been strained out. The 

esculenta) Diversity, Local Knowledge and Management in Eastern Indonesia

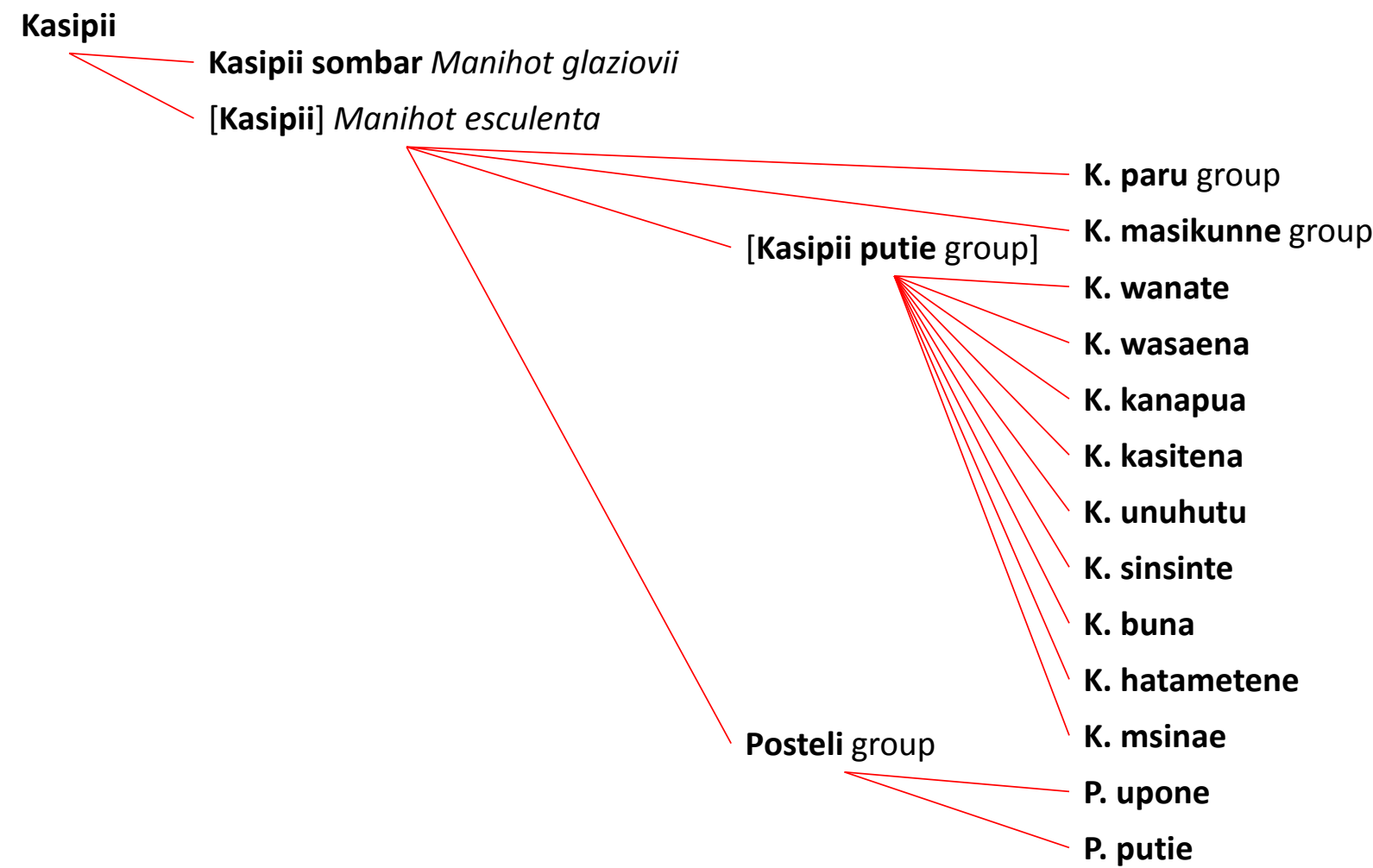

Figure 2. Indicative folk classification of Nuaulu category kasipii in Eastern Indonesia.

Table 2. Nuaulu cassava folk-variety names documented in Rouhua 2009, illustrating selected and simplified perceptual characters based on color and salient functional features. Key: $w=$ white, $b=$ black, $r=r e d, y=y e l l o w, r / w=r e d-$ dish white, $w / y=$ whitish yellow.

\begin{tabular}{|c|c|c|c|c|c|c|}
\hline \multirow[t]{2}{*}{ Nuaulu Term } & \multicolumn{5}{|c|}{ Plant Parts } & \multirow[t]{2}{*}{ Other characteristics } \\
\hline & 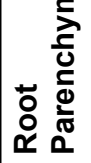 & $\frac{\xi}{\frac{5}{0}}$ & 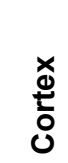 & $\frac{0}{\frac{0}{0}}$ & $\begin{array}{l}\frac{\varepsilon}{\Phi} \\
\text { ळे }\end{array}$ & \\
\hline kasipii unuhutu & w & w & r & - & w & roots: small (low edible content) \\
\hline kasipii paru [1] & w & - & w & $y$ & - & $\begin{array}{l}\text { leaves: long (same as wanate); roots: large (high edible } \\
\text { content), bitter }\end{array}$ \\
\hline kasipii paru [2] & w & - & - & y & - & leaves: fine; roots: bitter \\
\hline kasipii postel & w & - & - & $\mathrm{r}$ & - & $\begin{array}{l}\text { roots: few (but high edible content); tall, fast- growing; } \\
\text { stem lighter than paru, otherwise same outward char- } \\
\text { acters }\end{array}$ \\
\hline posteli tone & w & - & - & - & - & - \\
\hline posteli putie & w & - & - & - & - & - \\
\hline kasipii wanate & w & - & $r$ & - & - & leaves: long (same as paru) \\
\hline kasipii masikunne [1] & $\mathrm{y}$ & - & $\mathrm{y}$ & $\mathrm{y}$ & - & - \\
\hline kasipii masikunne [2] & $\mathrm{y}$ & $\mathrm{r}$ & $\mathrm{y}$ & - & - & - \\
\hline kasipii wasaena & w & - & $w / r$ & - & - & roots: largest of all folk-varieties, soft parenchyma \\
\hline kasipii kanapua & w & - & - & $w / y$ & - & - \\
\hline kasipii putie & w & - & $\mathrm{r}$ & - & - & - \\
\hline
\end{tabular}




\begin{tabular}{|c|c|c|c|c|c|c|}
\hline \multirow[t]{2}{*}{ Nuaulu Term } & \multicolumn{5}{|c|}{ Plant Parts } & \multirow[t]{2}{*}{ Other characteristics } \\
\hline & 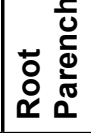 & $\begin{array}{l}\frac{5}{0} \\
\frac{0}{0} \\
\frac{0}{0} \\
0\end{array}$ & 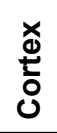 & $\begin{array}{l}\frac{0}{0} \\
\frac{0}{0} \\
0\end{array}$ & $\begin{array}{l}\varepsilon \\
\text { ڤँ } \\
\text { ڤे }\end{array}$ & \\
\hline kasipii kanapua & w & - & - & - & - & leaves: short \\
\hline kasipii sinsinte & w & - & - & - & - & leaves: variegated \\
\hline kasipii msinae & $w / r$ & $r$ & $r$ & $r$ & - & - \\
\hline posteli upone & w & - & - & - & - & - \\
\hline kasipii hata metene & w & - & $\mathrm{b}$ & - & - & - \\
\hline kasipii kasitena & w & - & - & - & - & - \\
\hline kasipii buna & w & - & - & - & - & leaves: variegated \\
\hline kasipii mata rase & w & - & - & $r$ & w & $\begin{array}{l}\text { good root productivity, and robust (see Table 1); other- } \\
\text { wise same as wasaena }\end{array}$ \\
\hline
\end{tabular}

lexical marking of toxicity implies a covert distinction in the folk classification, but this is not consistent. Names and the meanings of names are often matters for disagreement.

Plant height and root size are not, on the whole, good distinguishing characters. Some clones are regarded as 'short', often meaning that they will yield roots when still less than a meter high, or will flower when short. Similarly, yields can be enormously variable, and depend more on local ecology (soil nutrients, soil hardness, rainfall, stoniness, time of harvesting, co-planting regimes). All folk-varieties will have poorer yields in hard soils, and root size tends not to vary consistently in relation to folk-variety. Having said as much, people do claim that different folkvarieties have different yield potentials. For example, one masikunne plant yielded 6 roots at 2 kilos, which was thought to be usual, while wasaena is reputed to have the largest roots, unuhutu amongst the smallest, with posteli said to yield only small numbers. Nuaulu agree that, as a rule, high yields (in terms of overall weight, number of roots per plant and length of root) tend to be associated with swiddens that have been cut from mature forest, and that yields decrease as gardens get older, or in gardens cut from secondary growth, that have been planted many times before. Among the other folk-varieties, kasipii mata rase, found on ex-garden land, for example near streams, was formerly much grown, but is now scarce. It tends not to thrive in dry conditions as the stems dry out and die, but it is otherwise hard to kill off. In the past it was planted and replanted once or twice and then discarded.

There do not appear to be any major differences between the sexes in terms of the distribution of knowledge regarding cassava, though given the role of females in gardening and, nowadays, in marketing, it might be imagined that they have a more extensive knowledge. Variation is less obviously linked to socio-economic difference than to differences between individuals given their personal experience and priorities in different aspects of what is a broadspectrum subsistence strategy. For example, Saete, the present village headman, does not know unuhutu, knows sinsinte but does not grow it, and would grow kanapua if he had access to the stem cuttings.

\section{Nuaulu Cassava Management Practices}

It is not certain when cassava entered the Nuaulu food system, but it was a significant element in swiddens and in diet by 1970-71. At this time Nuaulu tended to plant cassava at the end of the first year swidden season, generally not before 300 days after the first planting of green vegetables and after taro, yams and sweet potato (Ellen 1978:161-7). This pattern has not changed much in 40 years. As a garden matures towards the end of the first year the species diversity will increase. However, on the basis of a comparison of garden maps made in 1970 and 2009 , the proportion of land devoted to cassava has increased, and cassava has tended to be planted earlier. There has also been an increase in the number of cassava folk-varieties recorded over the period. In 1971 five were recorded (Ellen 1973), though this is unlikely to have exhausted the number then in circulation; in 1996 11, and by 2009 this had increased to about 16. Although Nuaulu still widely express a preference for sago and other starchy roots as food, cassava produces relatively well on soils of lower fertility, the window of opportunity for harvesting is much longer, many folk-varieties can be left in the ground longer before harvesting, and it permits a smooth transition to fallow.

Nuaulu tend to mix many cultivated species, and planting decisions tend to be about the ratios of these rather than of folk-varieties of individual species. In 2009 Ellen com- 


\section{Ellen \& Soselisa - Socio-ecological Concomitants of Cassava (Manihot esculenta) Diversity, Local Knowledge and Management in Eastern Indonesia}

pared the planting preferences for five individuals, who were asked to freelist their top five folk-varieties, and also examined the composition of five gardens. In the freelisting exercise individuals often felt unable to rank the full five requested. Of the top three ranked, masikunne was the most frequently mentioned (5), followed by wasaena and paru (3 each), putie (2) and posteli (1). Of those top-ranked, putie was the most common (2), followed by wasaena, masikunne and paru (1 each). The reasons for not planting a particular type were often the unavailability of stem cuttings rather than a positive preference for something else.

Stems of cassava are used here as an estimate of number, as identifying discrete plants is often difficult because they are often multi-stemmed, and self-propogate through subterranean roots that may give rise to new stem clumps away from the mother plant. In terms of swidden composition, one first year garden of between 0.5 and 1 hectare contained approximately 116 cassava stems of which the overwhelming proportion (100) was putie, with 11 masikunne and 5 paru. Another larger mixed swidden on flat or gently rising land contained approximately 400 wasaena, masikunne and paru, but mostly wasaena and masikunne. In a second year swidden, cassava had already been replanted along a streamside. This was mostly putie (200 stems), but with some masikunne and paru. A mixed 6 month old swidden with at least 11 crop species contained masikunne, paru, wasaena, putie, hata metene, and kanapua, in roughly equal proportions, but probably more masikunne than anything else, and with the largest single patch devoted to paru (100+ stems). A four month swidden in the upstream area of the Rouhua river was mainly Xanthosoma, chilli and banana, but also contained 50 cassava stems of young wanate, about 30 stems of masikunne and a little paru. However, there was a lot of 'wild' unmanaged mature wanate in an adjacent old garden.

People say they would plant more folk-varieties if they could get the stem cuttings. On the whole, people plant by default, using whatever germplasm they have most of, though preferences must gradually influence the stock that is available. Moreover, what folk-varieties there are in a swidden at any one time is sensitive to highly seasonal factors, given its role as a fallback food. The outcome is a distribution of great patchiness, and a preference for diversity whatever the virtues of particular types.

All cassava diversity derives from the selection of clonal folk-varieties through stem cuttings. Stem cuttings are taken as each plant is harvested, replanted directly if the swidden is still regarded as having a future, stored in a garden hut, or often left laying on the ground half prepared for planting later. Where cassava is left unharvested and unmanaged it becomes lignified and weedy, and is not only found in old swiddens but along the wayside. Where discarded material is thrown, for example along the edges of gardens, streamsides and pathsides, older folk-varieties may persist, as here it has more opportunities to flower and reproduce sexually than in the active gardens. Flowering cassava plants are rare in Nuaulu swiddens. The reasons for this are not entirely clear, though flowering is undoubtedly stimulated by more challenging soil conditions, while it is known that premature abortion of inflorescences may prevent flowering (Veltkamp \& de Bruijn 1996:109).

The main risk factors encountered in Nuaulu cassava cultivation concern ensuring that most of the sweet folk-varieties are harvested at the period of maximum productivity, and before roots begin to lignify. Pig predation is also an issue, but mainly for the sweeter types: wanate in particular was mentioned in this connection. In some areas with high soil water content (e.g., Somau) cassava will rot, and these areas tend to be avoided. Insect pests are not perceived to be a problem though the caterpillar une putute (Ellen 1993: 172) is known to eat the leaves.

Nuaulu say that most cassava folk-varieties can be stored for up to two days if they have an abrasion, and up to seven days if the periderm is intact. Also, wet roots will not store as long as those that are dry, and deliberate drying will allow longer storage. Paru can be left for up to one hour in a sack and then sun-dried. Unless not properly dried, they will not be particularly bitter to taste at this stage. As the roots of paru do not rot under normal soil conditions and neither do they lignify, they can be left in the ground longer and often grow to enormous sizes. Ellen measured stems in quite young gardens at $5 \mathrm{~cm}$ diameter and $400 \mathrm{~cm}$ tall.

Seven males and five females, each from a different household, were asked to rank their taste preferences for different folk-varieties of cassava. On the whole, subjects found it difficult to rank beyond two or three types. This is partly because, apart from the distinctions between bitter and sweet, and between some sweet folk-varieties in terms of softness and palatability, taste is not a significant factor. Folk-varieties at rank 1 were weighted by four, those at rank 2 by three, and those at rank 3 by two, in order to obtain a simple measure of overall preference. The results are shown in Table 3.

It can be seen that there was an overwhelming preference for the sweet folk-varieties wasaena and masikunne amongst both males and females, while the bitter folkvariety paru was consistently ranked lower. Other sweet folk-varieties rarely featured in preferences. Looking at individual responses, some ranked masikunne higher than wasaena and others wasaena higher than masikunne. A few ranked masikunne and wasaena equal first, but all ranked paru lower than these two.

The consumption factors influencing Nuaulu cassava management are not taste alone but also incorporate pro- 
Table 3. Nuaulu taste preferences for different cassava folk-varieties (Manihot esculenta Crantz) ( $\mathrm{N}$ subjects = 12). Note: Data for seven males and five females, each from a different household. Subjects were asked to rank their taste preferences for different folk-varieties of cassava. Folk-varieties at rank 1 were weighted by four, those at rank 2 by three, and those at rank 3 by two, in order to obtain a simple measure of overall preference.

\begin{tabular}{|l|c|c|c|}
\hline $\begin{array}{l}\text { Cassava } \\
\text { folk-varieties }\end{array}$ & Overall & Male & Female \\
\hline Wasaena & 38 & 22 & 16 \\
\hline Masikunne & 30 & 18 & 12 \\
\hline Paru & 11 & 05 & 06 \\
\hline Wanate & 06 & 03 & 03 \\
\hline Kanapua & 04 & 04 & \\
\hline Posteli & 02 & 02 & \\
\hline Hata metene & 02 & 02 & \\
\hline
\end{tabular}

cessing properties. Thus, both masikunne and wasaena were reported by several subjects as being best for boiling and frying, while paru generally scored low because it takes some effort to prepare. Nuaulu generally boil or fry sweet cassava folk-varieties (that is all those other than paru). Occasionally they will bake the same in the fire, especially when in the forest or swidden where cooking tools may not be available. Paru is the only folk-variety used for suami, the Butonese term used for the slightly sour-tasting bread made by grating and pressing the fermented flour. By contrast, sweet wasaena is favored for saena (AM sinoli), made from heating cassava flour with grated coconut, although paru is sometimes used as well.

\section{Kei cassava terms and categories}

Inhabitants of Debut describe bitter cassava as enbal (for which we have collected at least 16 distinct folk-varieties) and sweet cassava as kasbi (for which we have also collected at least 17 distinct folk-varieties). Enbal grows better on drier and poorer soils, and is more resistant to pig depredations. Subjects insisted on separate preference rankings for kasbi and enbal, but as with the Nuaulu, management factors were rated more important than taste. Debut farmers are aware that toxicity is variable genetically and heavily micro-environmental. All enbal is detoxified through grating, pressing, drying and cooking, and few deaths or long-term ill-effects are reported (Soselisa \& Ellen n.d.).

What is immediately striking about Kei terminology and classification of cassava is the absence of a single clear unambiguous overarching term to describe all folk-varieties. For many subjects, the Kei term for M. esculenta is enbal. ${ }^{4}$ The category includes $M$. glaziovii, a recent introduction to Kei, which is called variously enbal getah, kasbi karet or enbal karet (literally 'rubber' enbal, referring to the trunk exudate), or enbal watan ('wild'), because its roots are regarded as inedible. However, the term kasbi is also used to refer to the entire range of types, cognate with AM kasbi. Some people say that kasbi is a type of enbal: there is enbal sursur or sorsor (sometimes enbal parut, AM 'grated') and enbal kasbi. Enbal kasbi is alternatively described in AM as enbal rebus or enbal makan. We conclude that the consensus view is that the term enbal is used polysemously, to refer: to (a) cassava as a whole, (b) bitter folk-varieties in contrast to kasbi, and (c) the biscuits made from bitter cassava. Nevertheless, the boundary between enbal and kasbi is permeable and often indistinct, some kasbi roots being inedible after a year because of accumulated toxicity, while some folk-varieties of enbal, such as ngangiar, have roots that some subjects say can be eaten if boiled and if they are young enough. The terms elicited during all fieldwork phases are listed in Table 4.

Debut Kei terminology for describing cassava variation, like that of the Nuaulu, involves distinguishing key diagnostic parts of the plant, which are not necessarily the terms used to describe the botanically comparable parts of other plants, and do not precisely map onto scientific plant anatomical nomenclature. However, for cassava: vuan is fruit, vatu is seed or other reproductive material (IND bibit), and stem cutting is enbal ngain naban (ngain naban = lit. 'stem seed'; AM stek or batang bibit); fuun is flower, roan is leaf, faar is petiole, ngain is main stem (in the case of woody plants), wa'ar is root and ihin refers to the swollen storage organ (literally meaning 'flesh', 'inside'). Color terms are prominent indicators, particularly [nga]metan (black), ngangiar (white), vulvul (red) and tom (yellow). Local characterization of the different folk-varieties recognized is set out in table 5 .

\section{Kei Cassava Management Practices}

General agricultural practices in Debut can best be described as small-scale swiddening on secondary growth scrub. We examined plots on the village fringe, in locations about 10-20 minutes walk from the village, and in the vicinity of a government-sponsored dryland agricultural project (Soselisa \& Ellen n.d.), each of which had slightly different characteristics. The general pattern, however, is that vegetation is cleared on an area not exceeding one hectare and burned, and crops planted for a couple of years, and then left to rest. Tectona grandis L.f. (IND kayu jati) trees are a particular feature of cultivated areas, where they are used as boundary mark-

4. The orthography for Kei words mainly follows that adopted by Ed Travis in his unpublished 'Draft Kei-English dictionary -28 Jan 2011', and we thank him for permission to access this unpublished manuscript. We have departed from this standard in particular cases, where advised to do so by authoritative local speakers and writers of the language. 
Ellen \& Soselisa - Socio-ecological Concomitants of Cassava (Manihot esculenta) Diversity, Local Knowledge and Management in Eastern Indonesia

Table 4. Kei terms for folk-varieties of Manihot esculenta Crantz, Debut 2009. Language key: AM, Ambonese Malay; IND, Indonesian. Note that names in AM are often the same as in standard IND. Therefore, here AM should be understood to refer to names that have come from speakers of AM and speakers of IND in the Moluccas. Codes preceded by R (Rouhua) and D (Debut) in final column refer to leaf samples extracted for DNA analysis.

\begin{tabular}{|c|c|c|c|c|}
\hline Kei Term & Meaning & Synonym & Meaning & Notes \\
\hline \multicolumn{5}{|l|}{ A. Enbal } \\
\hline enbal lislis & $\begin{array}{l}\text { fine, slender } \\
\text { [refers to leaflet] }\end{array}$ & laslis & ideolectal variant & D24 \\
\hline $\begin{array}{l}\text { enbal lislis ngain } \\
\text { ngangiar }\end{array}$ & white stem & $\begin{array}{l}\text { enbal lislis } \\
\text { batang putih }\end{array}$ & white stem(AM) & D21 \\
\hline $\begin{array}{l}\text { enbal lislis ngain } \\
\text { ngametan }\end{array}$ & black stem & \begin{tabular}{|l} 
enbal lislis \\
batang hitam
\end{tabular} & black stem (AM) & D19 \\
\hline $\begin{array}{l}\text { enbal ngangiar } \\
\text { ulin ma'afa }\end{array}$ & $\begin{array}{l}\text { white; thick skin } \\
\text { [root cortex] }\end{array}$ & $\begin{array}{l}\text { enbal ngangiar } \\
\text { kulit tebal }\end{array}$ & thick skin (AM) & D9, D26 \\
\hline $\begin{array}{l}\text { enbal ngangiar } \\
\text { har'u }\end{array}$ & white; ancient & - & - & D22 [see D25] \\
\hline enbal hukun hail & $\begin{array}{l}\text { breadfruit juice } \\
\text { [refers to stem } \\
\text { exudate] }\end{array}$ & - & - & $\begin{array}{l}\text { D11; breadfruit, } \\
\text { Artocarpus altilis } \\
\text { (Parkinson) Fosberg }\end{array}$ \\
\hline $\begin{array}{l}\text { enbal ngangiar } \\
\text { vaar vulvul }\end{array}$ & white; red petiole & $\begin{array}{l}\text { enbal putih } \\
\text { batang merah }\end{array}$ & $\begin{array}{l}\text { white; red } \\
\text { petiole (AM) }\end{array}$ & D17 \\
\hline enbal waleu & - & - & - & D7 \\
\hline enbal Tayad & $\begin{array}{l}\text { from Tayando } \\
\text { [toponym] }\end{array}$ & - & - & D3, D16 \\
\hline enbal tepong & $\begin{array}{l}\text { tepong = flour, } \\
\text { powdery (AM) }\end{array}$ & enbal Namar & $\begin{array}{l}\text { from Namar } \\
\text { [toponym] }\end{array}$ & $\begin{array}{l}\text { D4, D8; tepong } \\
\text { refers to texture of } \\
\text { root at certain age }\end{array}$ \\
\hline enbal tom har'u & yellow; ancient & - & - & D10 \\
\hline enbal ngangiar tom & white; yellow & - & - & D15 \\
\hline enbal Loon roan ket & $\begin{array}{l}\text { from Loon } \\
\text { [toponym]; short leaf }\end{array}$ & $\begin{array}{l}\text { enbal Loon } \\
\text { daun pendek }\end{array}$ & $\begin{array}{l}\text { from Loon } \\
\text { [toponym]; short } \\
\text { leaf (AM) }\end{array}$ & D12 \\
\hline $\begin{array}{l}\text { enbal Loon } \\
\text { roan baloat }\end{array}$ & $\begin{array}{l}\text { from Loon } \\
\text { [toponym]; long leaf }\end{array}$ & $\begin{array}{l}\text { enbal loon daun } \\
\text { panjang }\end{array}$ & $\begin{array}{l}\text { from Loon } \\
\text { [toponym];long } \\
\text { leaf (AM) }\end{array}$ & D13 \\
\hline enbal paped & sago porridge & - & - & $\begin{array}{l}\text { flour formerly } \\
\text { consumed in the } \\
\text { same way as } \\
\text { sago porridge } \\
\text { (AM, papeda) }\end{array}$ \\
\hline enbal Ngabub & $\begin{array}{l}\text { from Ngabub } \\
\text { [toponym] }\end{array}$ & - & - & - \\
\hline \multicolumn{5}{|l|}{ B. Kasbi } \\
\hline kasbi nas & $\begin{array}{l}\text { ngunas, frying } \\
\text { oil; nas, sugar }\end{array}$ & - & - & D18; [2 kinds] \\
\hline $\begin{array}{l}\text { kasbi nas daun } \\
\text { bulat pendek }\end{array}$ & short round leaf (AM) & - & - & - \\
\hline kasbi nas putih & white (AM) & - & - & $\begin{array}{l}\text { D29; from Seram } \\
\text { and Ambon }\end{array}$ \\
\hline
\end{tabular}




\begin{tabular}{|c|c|c|c|c|}
\hline Kei Term & Meaning & Synonym & Meaning & Notes \\
\hline kasbi naf ay & woody [refers to root] & nas bakayu & $\begin{array}{l}\text { woody (AM) } \\
\text { [refers to root] }\end{array}$ & D20 \\
\hline kasbi Mabut & $\begin{array}{l}\text { alias of person who } \\
\text { brought cutting }\end{array}$ & kasbi Tepa & town on Babar & $\begin{array}{l}\text { D14; Mabut is a } \\
\text { nickname for an } \\
\text { individual with } \\
\text { albinism or white } \\
\text { scar tissue }\end{array}$ \\
\hline kasbi putih & white (AM) & - & - & D31; from Seram \\
\hline \multirow[t]{2}{*}{ kasbi tom } & \multirow[t]{2}{*}{ yellow } & kasbi kuning telor & egg yellow (AM) & \multirow[t]{2}{*}{ D5 } \\
\hline & & kasbi kuning & yellow (AM) & \\
\hline kasbi tom har'u & yellow; ancient & - & - & - \\
\hline kasbi tom mas & yellow; gold & $\begin{array}{l}\text { kasbi tom kuning } \\
\text { tua }\end{array}$ & dark yellow (AM) & D30 \\
\hline $\begin{array}{l}\text { kasbi tom } \\
\text { vaar vulvul }\end{array}$ & yellow; red petiole & kasbi vulvul & red petiole & $\begin{array}{l}\text { D28; from } \\
\text { Seram } 2000\end{array}$ \\
\hline $\begin{array}{l}\text { kasbi tom (dari } \\
\text { Namar) }\end{array}$ & yellow & - & - & D32; from Namar \\
\hline kasbi Ambon & $\begin{array}{l}\text { from Ambon } \\
\text { [toponym] }\end{array}$ & - & - & D23 \\
\hline kasbi presiden [1] & president (IND) & - & - & $\begin{array}{l}\text { D6; from Warwut } \\
\text { (Kei Kecil) }\end{array}$ \\
\hline kasbi presiden [2] & president (IND) & - & - & $\begin{array}{l}\text { D34; from Rumadian } \\
\text { (Kei Kecil) }\end{array}$ \\
\hline kasbi ngangiar & $\begin{array}{l}\text { white [refers to } \\
\text { all characters] }\end{array}$ & - & - & $\begin{array}{l}\text { D1; } 2 \text { un-named } \\
\text { subtypes }\end{array}$ \\
\hline kasbi ‘enbal’ & (like) enbal & - & - & D2 \\
\hline kasbi kapas & cotton (wool) (AM) & & & $\begin{array}{l}\text { D27; from Ambon } \\
\text { around } 2000\end{array}$ \\
\hline kasbi Passo & $\begin{array}{l}\text { from Passo } \\
\text { [toponym] }\end{array}$ & kasbi putih kuning & white yellow (AM) & $\begin{array}{l}\text { D33; Passo is town } \\
\text { on Ambon island }\end{array}$ \\
\hline
\end{tabular}

Table 5. Some cassava (Manihot esculenta Crantz) folk-varieties in Debut, 2009: names (excluding synonyms) and selected and simplified morphological characters based on color. Key: $w=$ white, $b=$ black, $r=r e d, y=y e l l o w, r / w=$ reddish white, w/y = whitish yellow; k.o., kind of.

\begin{tabular}{|c|c|c|c|c|c|c|c|}
\hline \multirow[t]{2}{*}{ Name } & \multicolumn{6}{|c|}{ Plant Parts } & \multirow[t]{2}{*}{ Other characteristics } \\
\hline & 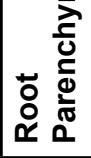 & $\frac{\underline{5}}{\frac{5}{0}}$ & 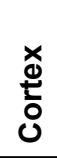 & $\frac{0}{\circ}$ & $\begin{array}{l}\varepsilon \\
ٍ \\
\omega\end{array}$ & 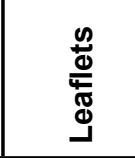 & \\
\hline \multicolumn{8}{|l|}{ A. Enbal } \\
\hline $\begin{array}{l}\text { enbal lislis ngain } \\
\text { ngangiar }\end{array}$ & w & $\mathrm{b}$ & w & $r$ & w & slender & $\begin{array}{l}\text { good storage roots ( } 2-3 \text { year in soil), highest } \\
\text { toxicity; flowers rare }\end{array}$ \\
\hline $\begin{array}{l}\text { enbal lislis ngain } \\
\text { ngametan }\end{array}$ & w & $b$ & w & $r$ & $b$ & slender & $\begin{array}{l}\text { roots as ngain ngangiar; leaflets longer than } \\
\text { ngain ngangiar; flowers rare; favored for } \\
\text { bubuhuk (k.o. food) }\end{array}$ \\
\hline
\end{tabular}


Ellen \& Soselisa - Socio-ecological Concomitants of Cassava (Manihot esculenta) Diversity, Local Knowledge and Management in Eastern Indonesia

\begin{tabular}{|c|c|c|c|c|c|c|c|}
\hline $\begin{array}{l}\text { enbal ngangiar } \\
\text { ulin ma'afa }\end{array}$ & w & $\mathrm{b}$ & w & w & w & round & roots: good storage; flowers rare \\
\hline $\begin{array}{l}\text { enbal ngangiar } \\
\text { har'u }\end{array}$ & w & $\mathrm{b}$ & w & w & w & round & flowers rare; old local variety \\
\hline enbal hukun hail & w & $\mathrm{b}$ & $r$ & w & w & round & flowers always; favored by pigs \\
\hline $\begin{array}{l}\text { enbal ngangiar } \\
\text { faar vulvul }\end{array}$ & w & $\mathrm{b}$ & w & $r$ & w & $\begin{array}{l}\text { colored } \\
\text { tips }\end{array}$ & flowers never \\
\hline enbal waleu & w & $\mathrm{b}$ & w & w & $\mathrm{b}$ & - & flowers always; old local variety \\
\hline enbal Tayad & w & $\mathrm{b}$ & w & $w / y$ & $\mathrm{~b}$ & dark red & $\begin{array}{l}\text { roots: fast-growing, good storage; good } \\
\text { (white) flour }\end{array}$ \\
\hline $\begin{array}{l}\text { enbal tepong/ } \\
\text { Namar }\end{array}$ & w & w & w & w & w & - & $\begin{array}{l}\text { roots optimal harvest at } 5-6 \text { months, } \\
\text { deteriorate after } 7 \text {; flowers rare; old local } \\
\text { variety }\end{array}$ \\
\hline enbal tom har'u & $\mathrm{y}$ & $\mathrm{b}$ & w & $r$ & $r$ & - & flowers rare; old local variety \\
\hline enbal ngangiar tom & $\mathrm{y}$ & $\mathrm{b}$ & w & w & $\mathrm{w}$ & - & - \\
\hline $\begin{array}{l}\text { enbal Loon } \\
\text { roan ket }\end{array}$ & w & $\mathrm{b}$ & w & $r$ & w & $\begin{array}{l}\text { black } \\
\text { tips }\end{array}$ & $\begin{array}{l}\text { rapid root maturation, good productivity; } \\
\text { flowers never }\end{array}$ \\
\hline $\begin{array}{l}\text { enbal Loon } \\
\text { roan baloat }\end{array}$ & w & $\mathrm{b}$ & w & w & w & - & roots occasionally woody; flowers never \\
\hline enbal paped & w & $\mathrm{b}$ & w & w & $\mathrm{b}$ & - & stem unbranched; extinct in Debut \\
\hline enbal Ngabub & - & - & w & $\mathrm{b}$ & $\mathrm{b}$ & black & roots: large, 3 yr maturation period \\
\hline \multicolumn{8}{|l|}{ B. Kasbi } \\
\hline kasbi nas putih & w & $\mathrm{b}$ & w & $r$ & w & - & roots: flowers at 3 months \\
\hline $\begin{array}{l}\text { kasbi nas } \\
\text { bakayu/naf ai }\end{array}$ & w & $\mathrm{b}$ & w & $r$ & $r$ & - & roots: few; flowers always \\
\hline kasbi nas & w & $\mathrm{b}$ & w & r & r & round & $\begin{array}{l}\text { flowers: always; favoured for frying and eating } \\
\text { with sugar }\end{array}$ \\
\hline $\begin{array}{l}\text { kasbi nas daun } \\
\text { bulat pendek }\end{array}$ & w & $\mathrm{b}$ & w & $r$ & w & $\begin{array}{l}\text { round/ } \\
\text { short }\end{array}$ & roots: high productivity; extinct in Debut \\
\hline kasbi mabut/Tepa & w & $\mathrm{b}$ & $\mathrm{r}$ & $\mathrm{r}$ & w & - & $\begin{array}{l}\text { roots: good food content after } 6 \text { months; } \\
\text { flowers } 3 \text { times; from } 3 \text { branches indicating } \\
\text { that roots are produced; stem red when young }\end{array}$ \\
\hline kasbi putih & w & w & w & w & w & - & $\begin{array}{l}\text { roots: flowers at } 2 \text { months can be harvested } \\
\text { at } 3 \text { months }\end{array}$ \\
\hline kasbi tom & $\mathrm{y}$ & $\mathrm{b}$ & w & $\mathrm{r}$ & w & round & crunchy roots; always flowers \\
\hline kasbi tom har'u & $\mathrm{y}$ & $\mathrm{b}$ & w & $r$ & $\mathrm{r} / \mathrm{w}$ & - & extinct in Debut \\
\hline kasbi tom mas & $\mathrm{y}$ & $\mathrm{b}$ & $\mathrm{y}$ & $\mathrm{y}$ & $w / y$ & round & flowers at 6 months \\
\hline $\begin{array}{l}\text { kasbi tom } \\
\text { faar vulvul }\end{array}$ & $\mathrm{y}$ & $\mathrm{b}$ & w & $\mathrm{r}$ & w & - & flowers at 6 months \\
\hline kasbi tom/Namar & $\mathrm{y}$ & $\mathrm{b}$ & w & $r$ & w & round & leaflets: wrinkled tips \\
\hline kasbi Ambon & w & $\mathrm{b}$ & r & r & r & round & roots: average of 10 per plant; always flowers \\
\hline kasbi presiden [1] & w & $\mathrm{b}$ & $r$ & $r$ & w & round & - \\
\hline kasbi presiden [2] & w & $w$ & w & w & w & - & - \\
\hline kasbi enbal & $\mathrm{r} / \mathrm{w}$ & $\mathrm{b}$ & w & $r$ & w & - & plants: bitter \\
\hline kasbi kapas & w & w & w & $r$ & $r / w$ & - & flowers at 6 months; \\
\hline kasbi Passo & $\mathrm{y}$ & w & w & $r$ & w & - & plants: still non-lignified at 12 months \\
\hline
\end{tabular}


ers and living fences, provide shade and are harvested for firewood.

The swiddens are mixed (predominantly with papaya, maize, Vigna sinensis (L.) Savi ex Hassk., coconut, banana and taro), but with a predominance of cassava. We collected data on number and combination of folk-varieties for a non-random but indicative selection of 16 plots. In 13 of these containing enbal, the range was between 1 and 9 folk-varieties, with a mean of 3.15. Different kinds of enbal lislis were the most frequently planted (10 plots) with enbal Tayad at 9 plots. In eight of the 16 plots containing kasbi, the range was between 1 and 5 folk-varieties, with a mean of 2.25. Overall, in all 16 plots sampled, the range was between 1 and 9 for all cassava folk-varieties, with a mean of 3.69. Some farmers prefer to plant either exclusively kasbi or enbal in one plot, though others (perhaps most) display a combination. However, in all cases, kasbi and enbal will be segregated within the plot. Different folk-varieties are planted in separate intermingled patches often with up to three-month intervals between patches for the duration of the life of the swidden. Mixed plots are preferred as they enable cassava to be harvested in rotation, provide for quick results and continuous availability, even if some folk-varieties perform poorly. One garden of about 1 hectare on the village fringe was mixed but visibly arranged in discrete patches of enbal lislis (3 months after planting), enbal ngangiar (already 12 months since planting and to be harvested in October), kasbi singkong (already 12 months since planting, but edible when boiled), enbal Tayad (to be harvested in October), enbal ngangiar (38 stem cuttings that will have to wait a year to harvest), kasbi tom faar vulvul (14 stem cuttings), and enbal lislis ( 75 stem cuttings at 3 months). Unlike the Nuaulu, the yellow root kasbi tom has low priority, and, for example, none is grown in the agri-project area.

In order to establish planting preferences for cassava folk-varieties, we took the top three preferences indicated by farmers for 16 plots, listing the preferences for kasbi and enbal separately. This is because farmers generally regarded the two categories to be non-commensurable. In each case, the top preference was awarded 3 points, the second preference 2 points and the third preference 1 point. Where there was an equal preference expressed, each of the folk-varieties concerned was awarded 2 points. For kasbi, in 8 of the 16 cases, farmers expressed no preference. Of the eight farmers that did express a preference, the highest preference was for nas, followed by ngangiar and Mabut equally. For 15 of the enbal cases all farmers were able to state a preference, overwhelmingly in favor of the quick-growing Tayad (21), followed by lislis ngain ngametan (12) and then equally ngangiar har'u and ngangiar ulin ma'afa (6 each). It will be noted that there is a close correspondence between the preference rankings and actual planting patterns recorded. Kasbi preferences tended to reflect rapid maturation rate, root productivity and taste, in particular consum- er preferences encountered in local markets (e.g., kasbi nas). Enbal preferences tended to reflect longer harvesting period, root productivity and quality, and resistance to pig depredations.

Cassava is thought best planted during November-December, in the wet season after burning in October. Kasbi is planted first, as it grows faster, then enbal. It is recognized that where you plant a stem cutting may have different consequences for the quality of root, and that this may vary according to folk-variety. So, while soft deep soils generally encourage larger roots in all folk-varieties, in the specific case of Mabut, cuttings planted on the edge of water will yield soft roots, though if planted in dry soil will yield hard roots. This was also found to be common to farmer knowledge on Seram and Buano. When a stem cutting is planted it is cut several times in different places to maximize the number of roots. In drier areas it is important for stem cuttings to be planted at an angle and most of them covered with soil. Nuaulu, by comparison are less particular in this respect. There is little grafting of one folkvariety on another, particularly of enbal onto kasbi rootstocks as suggested by the Department of Agriculture, as the preference is to keep patches of different folk-varieties separate.

Stem cuttings may be kept for several weeks before planting, and whole stems may be stored in garden shelters (pondok kebun) until needed to prepare stem cuttings for planting, though ideally these should be stored leaning against the wall and with their bases covered with soil. Also, if the stem cuttings are stored underneath a tree they are less likely to dry out quickly and can be later replanted.

Propagation is virtually always through the clonal planting of stem cuttings. However, while on Seram it was rare to see cassava (except for $M$. glaziovii) flowering and fruiting, this was common in Debut, where cassava will commonly flower. Enbal may flower when quite young, even fruiting after 5-6 months, while kasbi nas putih will flower at 3 months, and kasbi putih at 2 months. Flowering is most likely a feature of drier climatic regimes, an adaptation by plants under stress to ensure reproduction. This is redundant on Seram, where spontaneous vegetative reproduction seems to be more common. Fruiting may often be treated as a sign that there will be a reasonable harvest of roots after four months from planting. With its early flowering, kasbi putih can be harvested early, and the appearance of three flowers on the three branches of kasbi Mabut indicates that the plant is beginning to produce roots. No attempt is made by farmers to experiment by propagating seedlings that have arisen from fallen fruit, although a few did suggest that if fruits are planted they will likely yield roots. It is widely observed that seed dropped from cassava fruits will be eaten by birds, particularly cockatoos, which will then disperse the seed through defecation. Where F1 seedlings arise from such 


\section{Ellen \& Soselisa - Socio-ecological Concomitants of Cassava (Manihot esculenta) Diversity, Local Knowledge and Management in Eastern Indonesia}

seeds people call them enbal kanar tean, but note that harvestable roots are seldom found in the first generation, and that such seedlings suffer a high mortality, and therefore farmers tend to neglect them. In practice, of course, it is plausible that seedings naturally propagated in this way may become incorporated into the germplasm available to local farmers, and thereby increase genetic heterogeneity. McKey et al. (in press) suggest another reason why where sexual reproduction is evident it might not be encouraged by farmers: because it encourages frequent inbreeding which might destroy favorable trait combinations conserved in highly differentiated clonal folk-varieties, and because monovarietal patches within swiddens (certainly the rule in Debut) result in the clumping of clonemates. Because pollen is transported mainly between neighboring plants, this tends to result in highly inbred matings, while pollen transferred between highly differentiated folkvarieties in the same plot (again common in Debut) produces highly outcrossed offspring.

Pigs will generally devour roots described as kasbi, but are deterred by high levels of toxicity and the woodiness that comes with age in enbal. Protective fencing (ngean) is rare, but noose-traps (woar), sprung spear-traps (fanfan), pit-traps with wooden spikes placed along the edge of a garden (tar), or pig lances (nganga), are sometimes employed to deter pigs. There are now fewer wild pigs on Kei than 30 years ago, so there is less concern about potential damage, and fewer steps are taken to control for it. Other pests are regarded as manageable, including the parasitic vine war lanlanit.

Kasbi can be harvested after three months at the earliest and for a maximum of six months after planting, after which it lignifies and becomes too hard to eat as a whole root. People prefer enbal because it can be harvested between 8-12 months and oftentimes after a year (and up to three years), and need not be harvested quickly as it is less likely to lignify.

We collected data from 3 male and 8 female subjects from several different households, who were asked to rank their taste preferences for different folk-varieties. What was immediately apparent, in contrast to Rouhua, was the insistence on separate rankings for kasbi and enbal, and a preference for distinguishing preferences for kasbi in terms of taste, and for enbal (which are thought to be similar in taste) in terms of utility for processing. As with Rouhua, on the whole, subjects found it difficult to rank beyond two or three types. Clearly, the insistence on separating kasbi and enbal influences this, but as with Rouhua it appears that management factors rather than taste are overall more important in preference ranking, though ranking by taste and management preference is by no means consistent. We found that in the kasbi group there was a clear preference for kasbi nas in terms of taste (emphasizing softness and crispness), followed by kasbi ngangiar, kasbi Mabut and kasbi tom. In the en- bal group, preferences were not so clear, but with enbal lislis ranked first overall. A number of subjects claimed that both enbal lislis and enbal ngangiar made equally good flour and biscuits. Our data are too slight to confidently establish population-wide preferences by folk-variety and these data do not support any judgment concerning preference by gender.

Apart from taste, the food properties of enbal mentioned by Debut subjects included its ability to stave off hunger, as like sago the hard biscuits absorb water in the stomach and swell up. Although rice has become a preferred food for many (particularly younger villagers) and is generally available, it is usually combined with enbal at most meals. Many in Debut would acknowledge the truth of the proverb, Makan nasi cepat lapar, makan enbal lambat lapar ('If you eat rice you will get hungry quickly, if you eat enbal you will [only] get hungry slowly'), as well as subscribing to the view that you cannot eat enbal without fish.

\section{Comparison of Toxicity Across Different Research Sites}

All cassava cultivars, and all parts of the plant, contain cyanogenic glucosides (mainly linamarin) yielding toxic levels of hydrogen cyanide ( $\mathrm{HCN}$ ) by enzymic breakdown. Consequently, drawing a firm distinction between 'bitter' and 'sweet' is hard to justify in scientific terms, as all kinds of intermediates occur (Veltkamp \& de Bruijn 1996:10810). Although the correlation between glucoside content and taste is not straightforward, in local folk classifications this distinction is still important. One of our objectives was to compare the judgments of Nuaulu and Debut subjects as to the toxicity of different cassava folk-varieties with a scientific measurement of toxicity, to determine the reliability and utility of local knowledge embedded in folk classificatory distinctions. We used 'Bradbury' picrate tests on a portion of root to measure ppm (milligrams $\mathrm{HCN}$ per kilogram cassava) (Bradbury et al. 1999, Egan et al. 1998; but see also Ellen \& Soselisa n.d. for other references). Hidayat et al. (2000) report the use of similar techniques for 179 Indonesian cassava cultivars with a wide geographical distribution, though none from the Moluccas.

The Nuaulu tests were run on 12 August as one batch of nine samples collected between 9 and 11 August, and the results read 16 hours later on 13 August. The blank was $0 \mathrm{ppm}$ of $\mathrm{HCN}$ and the standard 50 , so the results were accepted as accurate. The Debut tests were run in two batches: batch 1 of 15 samples on 22 August and batch 2 of eight samples on 23 August, the results in each case being read 16 hours later on 23 and 24 August respectively. The blank for both batches was $0 \mathrm{ppm}$ and the standard for both batches $50 \mathrm{ppm}$, so the results were accepted as accurate. The detailed results are presented in Ellen \& Soselisa (n.d., tables 2 and 3). We found that for nine Nuaulu folk-varieties mean toxicity was $151 \mathrm{ppm}$ (range $=10-300 \mathrm{ppm})$ and for $23 \mathrm{Kei}$ folk-varieties 306 
ppm (range $=20-800)$. There was a considerable amount of overlap between those folk-varieties designated kasipii (all Nuaulu), kasbi ('sweet' Debut) and enbal ('bitter' Debut), though kasbi showed a mean of 206 ppm and enbal a mean of $360 \mathrm{ppm}$. The one Nuaulu folk-variety marked out as 'bitter', kasipii paru (from Buton) was 200 ppm (Ellen \& Soselisa n.d., Figure 3).

What is evident in comparing folk classifications of cassava in Rouhua and Debut is the importance of the distinction between kasbi and enbal in Debut and the absence of a comparable distinction in Rouhua. In the Debut data there are judgements made by individuals as to the toxicity of particular folk-varieties of enbal, of the kind 'enbal tepong is more poisonous than enbal lislis'. At one level, this seems to reflect the larger number and importance of bitter folk-varieties in the Debut case, but can also identify perceptual distinctions that support this difference in the classification, other than toxicity itself. The general literature on $M$. esculenta provides strong warnings as to the difficulty of finding stable morphological criteria that correspond with the difference between 'sweet' and 'bitter', since the distribution in toxicity is continuous across subspecific variants and highly sensitive to local ecological conditions, and indeed conditions in the micro-habitat of individual plants and of roots of a single plant.

In both Rouhua and Debut, but more so in the latter, leaf shape was thought to be a helpful indicator of potential toxicity. We found a variety of compound leaf shapes in Rouhua and Debut, all of which can be described as comprising a number of leaflets of elliptical or oblanceolate form. Overall size of leaves and the number of leaflets on an individual leaf, ranging between three and nine, correlates strongly with plant growth and is not self-evidently a helpful indicator of taxonomic difference, and subjects in both study sites noted that young leaves of all types are reddish when young but become green with maturation, and that single leaflets seem to occur on some old plants. However, subjects also consistently identified certain leaf shapes and other characters as typical of particular folk-varieties, and groups of folk-varieties; and in Debut some subjects claimed a relationship between hard soil and 'hard' leaf, and soft soil and 'soft' leaf. There are other studies of diasporic cassava that support this finding (Oluwolea et al. 2007, Rosling 2003).

In order to test whether leaf shape had any general relationship to toxicity, and specifically the distinction between kasbi and enbal in Debut, we measured the length and breadth of the median or nearest to median leaflet in centimeters and divided length by breadth to give an index of shape. Broadly, this meant that the higher the index the narrower the leaflet. Of eight specimens from seven different folk-varieties in Rouhua the index range was 2.9-9.5 with a mean of 4.35 . The only specimen (kasipii paru) in this sample indicated lexically as being problematically toxic had an index of 3.2. By comparison, of the 14 Debut specimens from 13 folk-varieties, 10 were designated kasbi (i.e., low toxicity) and 4 enbal (high toxicity). Kasbi specimens had a range of 3 - 4 and a mean of 3.6, while enbal specimens had a range of $2.6-9.33$ and a mean of 5.65. Thus, in the Rouhua case, where toxicity is less of an issue, the index for the more toxic folk-varieties are not evidently distinguishable from the rest, and our one measurement is less than the mean. However, in the Debut case, despite a large overlap in the range, the means were significantly different, and show evidence of an association between leaf shape and perceived toxicity. The Debut enbal mean is higher and the mean for kasbi lower than the Rouhua mean for all cassava, while the Debut mean for kasbi is higher than the one Rouhua folk-variety culturally-flagged for toxicity. This reflects the importance of folk-varieties perceived as toxic in the Debut case compared with Rouhua (Table 6).

Finally, we also tested at a third site, Buano, in order to obtain some sense of whether our general hypotheses were realistic. Soselisa had undertaken fieldwork on Buano in 1998-9, at a time of environmental instability and communal conflict (Soselisa 2007). Population displacement and economic disruption placed stress on resources, with cassava becoming of increased importance during dry periods, and particularly at the time of unrest. Bitter cassava (kasbi Obi) in particular appears to have become increasingly important during this period. Soselisa returned to Buano Selatan at the beginning of December 2009 and conducted picrate tests on 10 local cassava folk-varieties (two of which were flagged as 'bitter'). Because of exceptionally dry Table 6. Comparison of leaf size (Range \& Mean) index for Manihot esculenta Crantz and Manihot glaziovii Müll. Arg. folk-varieties in Rouhua and Debut.

\begin{tabular}{|l|l|c|l|c|c|c|}
\hline Location & Species & $\begin{array}{c}\text { Specimens } \\
(\mathbf{N})\end{array}$ & Folk groupings & $\begin{array}{c}\text { Folk-varieties } \\
(\mathbf{N})\end{array}$ & $\begin{array}{c}\text { Range } \\
(\mathbf{c m})\end{array}$ & Mean \\
\hline \multirow{2}{*}{ Rouhua } & \multirow{2}{*}{ M. esculenta } & 8 & all folk-varieties & 7 & $2.9-9.5$ & 4.35 \\
\cline { 3 - 7 } & & 1 & toxic only & 1 & 3.2 & 3.2 \\
\cline { 3 - 7 } & & 10 & kasbi & 9 & $3-4$ & 3.6 \\
\cline { 3 - 7 } & & 4 & enbal & 4 & $2.6-9.33$ & 5.65 \\
\hline & & 2 & kasipii sombar & 1 & $2.25-2.3$ & 2.27 \\
\hline
\end{tabular}

www.ethnobotanyjournal.org/vol10/i1547-3465-10-015.pdf seasonal conditions many cassava gardens were not productive. Buano Utara no longer produced sagu kasbi (fermented flour for making biscuits) due to a decrease in 


\section{Ellen \& Soselisa - Socio-ecological Concomitants of Cassava (Manihot esculenta) Diversity, Local Knowledge and Management in Eastern Indonesia}

the number of gardens, partly attributed to pig infestation. While the population of Buano Selatan had remained unchanged since 1998, the population of Buano Utara had more than doubled, from about 5000 to almost 11,000 in 2009. A new settlement had been established at Tanjung Kawa with more productive swiddens producing sagu kasbi (from both sweet and bitter cassava) for the inhabitants of Buano itself. On 10 December Soselisa recorded the following results for Buano Selatan: kasbi Obi buku kaluar (200 ppm), kasbi Obi biasa (100 ppm); kasbi boboita, kasbi bastel, kasbi kuning (batang kecil) and kasbi tahalupu (50 ppm); kasbi santri putih and kasbi putih (30 ppm), kasbi ular (20 ppm) and kasbi nasi (10 ppm), giving a mean $\mathrm{HCN}$ score of $59 \mathrm{ppm}$. This mean is much lower than either of those recorded for Rouhua and Debut, with fewer samples and a narrower range. However, the two folk-varieties flagged by local people as bitter have the highest scores.

\section{Comparison of the Agroecology of Research Sites}

If we compare the ecology and management of $M$. esculenta in the Nuaulu area of Seram and in Kei Kecil, we can see an interesting pattern of contrasts. The Nuaulu area has higher rainfall, greater forest cover (which allows for the retention of more moisture), higher soil fertility, lower human population density, complex vegecultural swiddens with high starch root diversity, while sago remains the primary source of starch. Kei experiences lower rainfall, is characterised by heavy deforestation, savanna, lower soil fertility, and higher human population density. There is lower starchy root crop diversity in swiddens and sago is much depleted. In Debut and Kei generally, sago appears to have preceded cassava. And we can see in the processing and consumption patterns of enbal certain continuities, such that the hard briquettes used in mortuary ceremonies and other ritual exchanges in parts of the Kei archipelago (Kaartinen 2007) resemble patterns of exchange elsewhere reliant on sago briquettes of similar appearance.

In the Nuaulu case, the ecological profile appears to be correlated with low cassava diversity, a low proportion of bitter folk-varieties, minimal management techniques, little evidence of regular flowering and fruiting, and therefore few volunteer seedlings. In Kei there are high levels of diversity, a high proportion of bitter folk-varieties, extensive management, much evidence of regular flowering and fruiting, and some evidence of volunteer seedlings, even though they are reckoned to be of no significance in introducing new genetic variation into the stock. Although we believe that in general terms the lower number of terms reported for Nuaulu compared with Debut reflects real genetic diversity, we acknowledge with Sambatti et al. (2001) that folk classifications tend to underestimate actual diversity, and we suggest Nuaulu do so more than Kei farmers. Indeed, DNA data for a group of folk-varieties from both sites indicates greater genetic diversity for few- er folk-varieties in Rouhua compared with greater differentiation reflected in folk-variety distinctions in a relatively smaller gene pool for Debut. The former suggests a more relaxed approach and the latter more active selection for phenotypical difference (Ellen \& Soselisa n.d., Ellen et al. n.d.). Nevertheless, data from both sites confirm the now well-known (Gibson 2009) advantages of folk-variety diversity reflected in perceptual distinctiveness as a strategy for risk management.

Despite these differences, the data from all research sites allow us to draw some tentative observations regarding the emerging biocultural history of cassava diversity in eastern Indonesia. Although toxicity is variable, as much due to micro-environmental factors as to genetics, folk classification provides a framework for making sense of toxicity. Moreover, in Debut there is a strong local correlation between leaf shape and perceived toxicity, and possible selection for perceptual distinctiveness (particularly evident for enbal lislis). Local differences in number and type of folk-varieties recorded reflect ecology, environmental change, previous food histories and human population movement. Given the environmental profile and other risk factors, we would expect the Buano data to lie somewhere between Rouhua and Debut. However, the number of folk-varieties and mean toxicity level is the lowest of all three sites, although circumstantial evidence does appear to suggest a greater interest in bitter cassava than in Rouhua.

These correlations are generally consistent with recent work on the chemical ecology of cassava which shows that polymorphism for cyanogen levels facilitates analysis of how costs and benefits of crop defenses vary between different human populations with different management regimes. In the light of this, it is not surprising that in Debut more enbal than kasbi is planted, and that the ratio of enbal to kasbi harvested is even greater. High cyanogen levels appear to confer important ecological advantages in terms of pest resistance (Bellotti \& Riis 1994), poor soils and low rainfall, and consequent agronomic advantages. Thus, bitterness appears to be selected for where competition is toughest. Such positive factors must be offset against health costs and constraints imposed by high levels of toxicity, and the need for effective detoxification processes or dietary buffers (McKey et al. 2010). Moreover, where local populations are under nutritional and economic stress, there are advantages in being able to harvest early-yielding varieties and in diversifying these, which tend to be sweet rather than bitter. We found this to be the case in both Debut and in Buano.

\section{Homeland and Diaspora Compared}

If our comparison of Rouhua and Debut can be said to reflect different modalities of biocultural adaptation involving $M$. esculenta within eastern Indonesia, then these data taken together tentatively point to some emerging dif- 
ferences in ecology and management between lowland South America and eastern Indonesia, and perhaps in the cassava diaspora more generally. Thus, because the New World represents the area of endemism and original domestication, there is more evidence of interbreeding with wild types (Rival 2001: 66-7) and therefore opportunities for taking advantage of new genetic combinations. Because there are more species of Manihot (about 200) and other closely-related Euphorbs, there has also been a longer time for pests to co-evolve as competitors, and for toxicity levels to be selected as a mechanism for coping with this (Bellotti \& Riis 1994). Moreover, regular flowering and fruiting has permitted the incorporation of volunteer seedlings (Rival 2001:65) in a way that is absent in our Indonesian sites. Indeed, recombinant volunteers derived from self-set seeds are the main source of genetic diversity and of newly identified landraces in the Amazon (Elias et al. 2001b, Pujol et al. 2007, Salick et al. 1997:12-5), while generally in lowland South America we find a large number of recognized folk-varieties and a greater proportion of sweet to bitter.

In the Old World diaspora there are no wild types, and therefore no cross-pollination. Germplasm is dispersed almost entirely through human agency. Moreover, flowering and fruiting are variable (and in some areas the plant seldom flowers), and there is little evidence for incorporation of volunteer seedlings, either deliberate or inadvertent. Unlike Amazonia (Boster 1984a, Rival \& McKey 2008:1120), the paradox of high diversity and clonal reproduction in our research sites cannot be adequately explained as a consequence of sexual reproduction, though none of the cases examined exhibit the local 'hyperdiversity' reported for Amazonia.

Compared with 35 significant arthropod pest species recorded for the Americas, there are only 15 for Africa, and 9 for Asia (Bellotti 2001:211), and three viral diseases in Asia compared with six in the Americas (Calvert \& Thresh 2001:238). Indeed, cassava mosaic disease (Calvert \& Thresh 2001:252) is the only virus known to be important in Southeast Asia and the Pacific, and in Indonesia a report from 1931 was later revised because the symptoms could be better explained as mineral deficiency. While 38 bacterial, fungal and nematode pathogens have been reported worldwide (Hillocks \& Wydra 2001:263, 274), only bacterial blight and one nematode infestation are reported for Asia, and then not thought significant. Thus, the absence of natural competitors and pathogens, whether viral, bacterial or fungal, give cassava the characteristics of an invasive species in many diasporic contexts. Vegetative propagation through stem cuttings is more rapid than sexual reproduction, and the longer the cutting and the more horizontally it is planted, the greater the number of shoots (Veltkamp \& de Bruijn 1996:108). Moreover, while weeding is necessary to begin with, after three months the plant canopy itself provides sufficient cover to inhibit weed growth. And although its vigorous vegetative repro- duction means that once introduced it is difficult to eradicate, on balance this vigor increases its value to humans in pioneer and dry marginal environments. Cassava will even shed its leaves in dry periods, but regrow them and resume growth. It can resist severe drought, making it a suitable crop for areas with uncertain rainfall distribution. It can produce reasonable yields continuously on dry, severely depleted and eroded soils, unsuitable for other crops, and on acidic soils with $\mathrm{pH}$ ranging from 4.5 to 6.5 and with low organic matter (Onwueme 2001:55), conditions where it has proved particularly valuable in the diaspora. Here, generally, lower numbers of folk-varieties have been recognized, though relatively more folk-varieties and a greater proportion of bitter phenotypes under more challenging agricultural conditions. Population pressure, economic crises and environmental change (Ellen 2007) will likely result in increasing reliance on cassava in Indonesia (see e.g., Hidayat et al. 2000). But while there are obviously differences between the biocultural context of the Old and New Worlds (most critically the absence of a long human-plant coevolutionary history outside of South America), this study shows that cultural and natural selection continue to shape cassava diversity through the knowledge, categorization, and valorization of phenotypically expressed differences.

\section{Acknowledgments}

This project has been funded by the British Academy ASEASUK Research Committee. Fieldwork was conducted under the auspices of Pattimura University within the terms of a Memorandum of Understanding with the University of Kent. We would like to thank the following: in Ambon: Rosemary Bolton, Hunanatu Matoke, Thomas Namsa and Kristina Ingratubun; in Canterbury: Simon Platten, Paul Gilbert and Rory McBurney; on Seram: Saete Soumori, Anakota, Son, Retaone, and Heunaka; on Kei: Karel Ohoiwutun (Bapa Sekretaris, Debut) and his wife Lina, Tante Agu, Agus Namsa and his wife Tin, Alfons ('Menyala') Yanlean, Mama Biba Jamlean and John Letsoin. We would like to thank Howard Bradbury and Gerard O'Brien for technical advice on the measurement of toxicity

\section{Literature Cited}

Barraud, C. 1985. Some aspects of millet cultivation in Tanebar-Evav (Kei-islands). Unpublished paper delivered at Seminar Penelitian Indonesia Bagian Timur, 23-29 July 1985. Lembaga Ekonomi dan Kemasyarakatan NasionalLIPI dan UNSRAT.

Bellotti, A.C. 2001. Arthropod pests. Pp. 209-235 in Cassava: Biology, production and utilization. Edited by R.J. Hillocks, J.M. Thresh \& A.C. Belotti. CABI Publishing, Wallingford, United Kingdom. 


\section{Ellen \& Soselisa - Socio-ecological Concomitants of Cassava (Manihot esculenta) Diversity, Local Knowledge and Management in Eastern Indonesia}

Bellotti, A.C. \& L. Riis. 1994. Cassava cyanogenic potential and resistance to pests and diseases. Acta Horticulturae 375:141-151.

Berlin, B., D.E. Breedlove \& P.H. Raven. 1973. General Principles of Classification and Nomenclature in Folk Biology. American Anthropologist 75:214-242.

Boster, J.S. 1983. A comparison of the diversity of Jivaroan gardens with that of the tropical forest. Human Ecology 11(1):47-68.

Boster, J.S. 1984a. Classification, cultivation, and selection of Aguaruna cultivars of Manihot esculenta (Euphorbiaceae). Advances in Economic Botany 1:34-47.

Boster, J.S. 1984b. Inferring decision making from preferences and behavior: an analysis of Aguaruna Jivaro manioc selection. Human Ecology 12:343-358.

Boster, J.S. 1985. Selection for perceptual distinctiveness: Evidence from Aguaruna cultivars of Manihot esculenta. Economic Botany 39:310-325.

Boster, J.S. 1986. Exchange of varieties and information between Aguarana manioc cultivators. American Anthropologist 88:428-436.

Bradbury, M.G., S.V. Egan \& J.H. Bradbury. 1999. Picrate paper kits for determination of total cyanogens in cassava roots and all forms of cyanogens in cassava products. Journal of the Science of Food and Agriculture 79:593601.

Calvert, L.A. \& J.M. Thresh. 2001. The viruses and virus diseasers of cassava. Pp. 237-260 in Cassava: Biology, production and utilization. Edited by R.J. Hillocks, J.M. Thresh \& A.C. Belotti. CABI Publishing, Wallingford, United Kingdom.

Clawson, D.L. 1985. Harvest security and intraspecific diversity in traditional tropical agriculture. Economic Botany. 39:56-67.

Donner, W. 1986. Land Use and Environment in Indonesia. Hurst, London.

Egan, S.V., H.H. Yeoh \& J.H. Bradbury. 1998. Simple picrate paper kit for determination of the cyanogenic potential of cassava flour. Journal of the Science of Food and Agriculture 76:39-48.

Elias, M., O. Panaud \& T. Robert. 2000. Perception and management of cassava (Manihot esculenta Crantz) farming system using AFLP markers. Heredity 85:219230.
Elias, M., D. McKey, O. Panaud, M.C. Anstett, L. Penet \& T. Robert. 2001a. Traditional management of cassava morphological and genetic diversity by the Makushi Amerindians (Guyana, South America). Perspectives for Onfarm Conservation of Genetic Resources 120:143-157.

Elias, M., L. Penet, P. Vindry, D. McKey, O. Panaud \& T. Robert. 2001b. Unmanaged sexual reproduction and the dynamics of genetic diversity of a vegetatively propagated crop plant, cassava (Manihot esculenta Crantz), in a traditional farming system. Molecular Ecology 10:1895-1907.

Ellen, R.F. 1973. Nuaulu Settlement and Ecology: An approach to the environmental relations of an Eastern Indonesian community. Ph.D. Dissertation. University of London.

Ellen, R.F. 1978. Nuaulu Settlement and Ecology: An approach to the environmental relations of an Eastern Indonesian community. Verhandelingen van het Koninklijk Instituut voor Taal-, Land- en Volkenkunde, 83. Martinus Nijhoff, The Hague.

Ellen, R.F. 1993. Nuaulu Ethnozoology: A systematic inventory. (CSAC Monographs, 6) Centre for Computing and Social Anthropology and Centre for Southeast Asian Studies, University of Kent, Canterbury, United Kingdom.

Ellen, R.F. 2006. Local knowledge and management of sago palm (Metroxylon sagu Rottboell) diversity in South Central Seram, Maluku, eastern Indonesia. Journal of Ethnobiology 26(2):83-123.

Ellen, R.F. 2007. Introduction. Pp. 1-45 in Modern Crises and Traditional Strategies: Local ecological knowledge in island Southeast Asia. Edited by R. Ellen (Studies in Environmental Anthropology and Ethnobiology, 6). Berghahn, Oxford, United Kingdom.

Ellen, R.F. 2010. Why aren't the Nuaulu like the Matsigenka? Knowledge and categorization of forest diversity on Seram, eastern Indonesia. Pp. 116-140 in Landscape Ethnoecology: Concepts of biotic and physical space. Edited by L.M. Johnson \& E. S.Hunn. Berghahn, Oxford.

Ellen, R.F. \& H.L. Soselisa. n.d. Cassava diversity and toxicity in relation to environmental degradation and food security in the Moluccas. in Environmental Uncertainty and Local Knowledge: Southeast Asia as a laboratory of global change. Edited by A.-K. Hornidge \& C. Antweiler. Transcript Global Studies, Bielefeld.

Ellen, R.F., H.L. Soselisa \& A.P. Wulandari. n.d. The biocultural history of Manihot esculenta in eastern Indonesia: Assessing evidence for the movement and selection of cassava germplasm. Submitted. 
Gade D. 2002. Names for Manihot esculenta: Geographical variation and lexical clarification. Journal of Latin American Geography 1:55-74.

Gibson, R.W. 2009. A review of perceptual distinctiveness in landraces including an analysis of how its roles have been overlooked in plant breeding for low-input farming systems. Economic Botany 63:242-255.

Hames, R.B. 1983. Monoculture, polyculture, and polyvariety in tropical forest swidden cultivation. Human Ecology 11(1):13-34

Harris, D.R. 1980. Tropical savanna environments: definition, distribution, diversity and development. Pp. 3-27 in Human Ecology in Savanna Environments. Edited by D.R. Harris. Academic Press, London.

Heckler, S. \& S. Zent. 2008. Piaroa manioc folk-varieties: hyperdiversity or social currency. Human Ecology 36 : 679-697.

Hidayat, A., N. Zuaraida, I. Hanarida \& D.S. Damardjati. 2000. Cyanogenic content of cassava root of 179 cultivars grown in Indonesia. Journal of Food Composition and Analysis 13:71-82.

Hill, R.D. 2004. Towards a model of the history of 'traditional' agriculture in Southeast Asia. Pp. 19-45 in Smallholders and Stockbreeders: History of foodcrop and livestock farming in Southeast Asia. Edited by P. Boomgaard \& D. Henley. KITLV Press, Leiden.

Hillocks, R.J. \& K. Wydra 2001. Bacterial, fungal and nematode diseases. Pp. 261-280 in Cassava: Biology, production and utilization. Edited by R.J. Hillocks, J.M. Thresh \& A.C. Belotti. CABI Publishing, Wallingford, United Kingdom.

Iskandar, J. \& R.F. Ellen. 1999. In situ conservation of rice landraces among the Baduy of West Java. Journal of Ethnobiology 19(1):97-125.

Kaartinen, T. 2007. Nurturing memories: The cycle of mortuary meals in an East Indonesian village. Pp. 149169 in Kinship and Food in South East Asia. Edited by M. Janowski \& F. Kerlogue. NIAS Studies in Asian Topics, 38. NIAS Press, Copenhagen.

McKey, D., T.R. Cavagnaro, J. Cliff \& R. Gleadow. 2010. Chemical ecology in coupled human and natural systems: People, manioc, multitrophic interactions and global change. Chemoecology 20(2):109-133.

McKey, D. B., M. Elias, B. Pujol \& A. Duputié. In press. Ecological approaches to crop domestication. In Biodiversity in Agriculture: Domestication, evolution and sustainability. Edited by P. Gepts, R. Bettinger, S.B. Brush, T.
Famula, P.E. McGuire \& C.O. Qualset. Cambridge University Press, Cambridge.

Maluku Dalam Angka. 2010. Badan Pusat Statistik Provinsi Maluku, Ambon.

Maluku Tenggara Dalam Angka. 2010. Badan Pusat Statistik Kabupaten Maluku Tenggara, Tual, Indonesia.

Monk, K. A., Y. de Fretes \& G. Reksodiharjo-Lilley. 1997. The Ecology of Nusa Tenggara and Maluku. Periplus, Hong Kong.

Nutz, W. 1959. Eine Kulturanalyse von Kei: Beiträge zur Vergleichenden Völkerkunde Ostindonesiens. Michael Triltsch Verlag, Düsseldorf.

Oluwolea, O.S., A.O. Onabolub, K. Mtundac \& N. Mlingid. 2007. Characterization of cassava (Manihot esculenta Crantz) varieties in Nigeria and Tanzania, and farmers' perception of toxicity of Cassava. Journal of Food Composition and Analysis 20:559-567.

Onwueme, I.C. 2001. Cassava in Asia and the Pacific Pp. 55-65 in Cassava: Biology, production and utilization. Edited by R.J. Hillocks, J.M. Thresh \& A.C. Belotti. CABI Publishing, Wallingford, United Kingdom.

Pujol, B., F. Renoux, M. Elias, L. Rival \& D. McKey. 2007. The unappreciated ecology of landrace populations: Conservation consequences of soil seed banks in Cassava. Biological Conservation 136: 541-551.

Rival, L. 2001. Seed and clone: A preliminary note on manioc domestication, and its implication for symbolic and social analysis. Pp. 57-79 in Beyond the Visible and the Material: The Amerindianization of society in the work of Peter Rivière. Edited by L. Rival \& N. Whitehead. Oxford University Press, Oxford, United Kingdom.

Rival, L, M. Elias \& D. McKey. 2000. Perception and management of cassava (Manihot esculenta Crantz) diversity among Makushi Amerindians of Guyana (South America). Journal of Ethnobiology 20(2):239-265.

Rival, L. \& D. McKey. 2008. Domestication and diversity in manioc (Manihot esculenta Crantz ssp. esculenta, Euphorbiaceae). Current Anthropology 49(6):1119-1128.

Rosling, H. 2003. Classification of cassava into 'bitter' and 'cool' in Malawi: From farmers' perceptions to characterisation by molecular markers. Euphytica 132:7-22.

Salick J, N. Cellinese \& S. Knapp. 1997. Indigenous diversity of cassava: Generation, maintenance, use and loss among the Amuesha, Peruvian Upper Amazon. Economic Botany 51(1):6-19. 


\section{Ellen \& Soselisa - Socio-ecological Concomitants of Cassava (Manihot esculenta) Diversity, Local Knowledge and Management in Eastern Indonesia}

Sambatti, J.B., M.P.S. Martins \& A. Ando. 2001. Folk taxonomy and evolutionary dynamics of cassava: A case study in Utatuba, Brazil. Economic Botany 55:93-105.

Soselisa, H.L. 2007. A comparison of traditional and innovative subsistence strategies on Buano during periods of socio-environmental stress, 1980-2003. Pp. 143-165 in Modern Crises and Traditional Strategies: Local ecological knowledge in island Southeast Asia. Edited by R.F. Ellen. Berghahn, Oxford.
Soselisa, H.L. \& R.F. Ellen. n.d. The management of cassava toxicity and its socio-cultural profile in the Kei Islands, eastern Indonesia. [In prep with the authors.]

Veltkamp, H.J. \& G.H. de Bruijn. 1996. Manihot esculenta Crantz. Pp. 107-113 in Plant Resources of South-east Asia No. 9. Plants yielding non-seed carbohydrates. Edited by M. Flach \& F. Rumawas. Backhuys, Leiden. 
